\title{
The Effect of Hedonic Motivation and Consumer Attitudes Towards Purchase Decision on K-Pop CD Albums (Study on KPOPSURABAYA Community)
}

\author{
Devita Anggraini Lestari ${ }^{1}$, Monika Tiarawati ${ }^{2}$ \\ State University of Surabaya \\ devitalestari1@mhs.unesa.ac.id, monikatiarawati@unesa.ac.id
}

\begin{abstract}
The rapid enthusiasm of Korean pop music or K-Pop is very high among the millennial generation. The mushrooming of online music streaming like Joox, Spotify, Apple music has made the CD album sales threatened. However, K-Pop fans apparently are still enthusiastic about buying a CD album even though the price is quite expensive. This study discusses the hedomic motivations and consumers attitudes towards purchasing decisions. This type of research used in this study is a combination of purposive sampling techniques. Data collection is done by using an online questionnaire using Google forms. The statistical analysis used in this study uses SPSS and data analysis techniques in this study use the classic assumption test, multiple linear regression analysis, and hypothesis testing. It can be explained that the results of the analysis show that hedonic motivations and consumer attitudes has significant influential on purchasing decisions.
\end{abstract}

Keywords: Consumer Attitudes, Hedonic Motivation, Purchase Decision

\section{INTRODUCTION}

The mushrooming of boyband's or girlband's concert tours in Indonesia shows that how much Korean music is more interested in this country compared to other countries' musicians marked by a Super Junior concert titled Super Show 4 on April 2012 in Indonesia that makes Indonesian music fans love them. Indonesia became a stop on their concert tour, such as BIGBANG, 2NE1, 2PM, to BTS.

According to Franki Raden (2014) in (Zaini, 2017), the development of K-pop due to the availability of infrastructure and mechanisms, Korea has succeeded in instilling awareness of the importance of music in people's daily lives. As a result, music consumption in Korea is very high, both for traditional music, pop, rock, jazz and classical music.

In a purchase decision there is a price to pay to get a CD album. The price of a CD album is quite expensive at around hundreds of thousands of rupiah, following a table of K-Pop CD album price ranges: 
THE SPIRIT OF SOCIETY JOURNAL

International Joumal of Society Development and Engagement

ISSN : 2597-4777 (Online) - ISSN : 2597-4742 (Print)

This work is licensed under a Creative Commons Attrib ution-ShareAlike 4.0 International License.

Table 1. Price Range of K-Pop CD Albums

\begin{tabular}{cclc}
\hline No & Group Name & $\begin{array}{c}\text { Album Title } \\
\text { and year }\end{array}$ & Price \\
\hline \multirow{2}{*}{1} & \multirow{2}{*}{ BTS } & $\begin{array}{l}\text { Love Yourself (2018) } \\
\text { Map of The Soul: } \\
\text { Persona (2019) }\end{array}$ & $\begin{array}{c}\text { Rp. 295.000 } \\
\text { Rp. 210.000 }\end{array}$ \\
\hline \multirow{2}{*}{2} & \multirow{2}{*}{ EXO } & $\begin{array}{l}\text { DMUMT (2018) } \\
\text { OBSESSION (2019) }\end{array}$ & $\begin{array}{l}\text { Rp. } 300.000 \\
\text { Rp. 150.000 }\end{array}$ \\
\hline \multirow{2}{*}{3} & \multirow{2}{*}{ TWICE } & $\begin{array}{l}\text { BDZ (2018) } \\
\text { \&Twice (2019) }\end{array}$ & $\begin{array}{l}\text { Rp. 200.000 } \\
\text { Rp. 400.000 }\end{array}$ \\
\hline
\end{tabular}

Source: processed data source

Based on table 1 above it can be concluded that BTS sells CD albums with a price range from 210 thousand to 295 thousand rupiah with Love Yourself (2018) and Map of the Soul: Persona (2019). Next, EXO sells the album from range 150 thousand to 300 thousand rupiah on DMUMT (2018) and OBSESSION (2019) albums and Twice selling album with the range of the price of 200 thousand up to 400 thousand rupiah on BDZ (2018) to \&Twice (2019) albums. Here the sales of CD albums ranging from 2016 until 2019 according to (Gaon Chart, 2019) as follows:

Table 2. CD Album Sales Data for 2016 - 2019

\begin{tabular}{cccccc}
\hline No & $\begin{array}{c}\text { Group } \\
\text { Name }\end{array}$ & $\mathbf{2 0 1 6}$ & $\mathbf{2 0 1 7}$ & $\mathbf{2 0 1 8}$ & $\mathbf{2 0 1 9}$ \\
\hline 1 & BTS & $1,119,670$ & $2,261,845$ & $4,047,345$ & $6,218,254$ \\
\hline 2 & EXO & $1,506,599$ & $1,921,158$ & $1,951,879$ & $1,970,306$ \\
\hline 3 & TWICE & 350,852 & $1,048,746$ & 870,592 & $1,191,537$ \\
\hline \multicolumn{5}{l}{ Source: researchers processed data (Chart, 2019) } \\
\end{tabular}

Based on table 2, it can be concluded that CD album sales have increased every year, but in each individual group sales there has been an increase and decline. Shown on the table that an increase in BTS and EXO sales, but TWICE rise and decline in album sales.

K-Pop lovers are motivated to buy their idol CD, VCD or DVD albums because they feel it is a natural thing and even a necessity to show their love. Although the money must be spent quite a lot. (Zaini, 2017)

A purchase is based on a purchase decision. Purchasing decision is a process where consumers recognize the problem, find information about a particular product or brand and evaluate how well each alternative can solve the problem, which then leads to a purchasing decision (Tjiptono, 2008). Factors that influence purchasing decisions are cultural, social and personal factors. Personal factors are age and family life cycle, work and economic environment, lifestyle, personality, psychological. Psychologically there are four factors namely motivation, perception, learning, beliefs and attitudes (Kotler, 2003). 
In all business industries, motivation plays an important role in the consumer purchasing process. Motives come from individual needs where there is strong pressure to fulfill satisfaction and pleasure (Kotler and Armstrong, 2011:147).

Consumer motivation is divided into two types namely utilitarian motivation and hedonic motivation. Utilitarian motivation is motivation for shopping because the needs or products purchased have benefits (Utami, 2010:59). Hedonic motivation is motivation that arises because of psychological needs such as satisfaction, prestige, emotions and other subjective feelings. Where these needs arise in order to meet social and aesthetic demands and can be referred to as emotional motivation (Sumarwan, 2011:25). There are six factors that can influence hedonic motivation namely adventure, gratification, role, value, social, and idea shopping.

Attitudes according to Mowen and Minor (2002) state that attitudes are the core of likes and dislikes for people, groups, situations, objects, and certain intangible ideas. Every element in this definition is very important to understand why and how attitudes are related in consumer behavior.

Aldaning et al (2018), Kusuma et al (2013) suggest that hedonic motivation has a significant effect on purchasing decisions. The results of the research by Adilang et al (2014) have a simultaneous and partial influence on attitudes and hedonic motivation on purchasing decisions. Then research Yuldinawati and Ayuningsari (2016) states that the adventure of shopping, shopping gratification, role and value shopping influence on consumer purchasing decisions. While social shopping and shopping ideas do not significantly influence purchasing decisions.

Results of research on attitudinal variables in the study Miauw (2016), Dasuki (2015), Yi et al (2013), which has a positive effect attitude on purchasing decision. However, Kapantouw and Mandey (2015) research shows that attitude has no significant and positive influence on purchasing decisions and Wattimena et al (2012) show cognitive and affective variables, conative of consumer attitudes has no positive and significant effect on purchasing decisions.

In this study the researchers chose KPOPSURABAYA community with 143 followers. This community was chosen because it includes various kinds of fans, it could be a boyband and also a girlband. This community only on social media called Line.

\section{METHOD}

The approach in this study uses a descriptive approach. The data in this study were analyzed quantitatively. In this research, the population has a finite which means the number of the population in question has been known. In this study, the population is the KPOPSURABAYA community with total 143 followers. The sample technique of this study used a non - probability sampling technique. Then for sampling using a purposive sampling method.

\section{RESULTS}

In this study, analyzing the effect of hedonic motivation and consumer attitudes on purchasing decisions for K-Pop CD albums on the KPOPSURABAYA community by spreading online questionnaires to 30 respondents whose validity and reliability were tested. Characteristics of respondents in this study were described in sex, occupation, age and expense. 
In the hedonic motivation variable, the highest average respondent's answer is 4.32 included in the strongly disagree category which is highly valued by the hedonic motivation. Then the lowest average respondent's answer is 3.94 included in the agreed category which indicates that the hedonic motivation towards the K-Pop cd album is very high.

On the consumer attitude variable, the highest average respondent's answer was 4,56 included in the category is strongly agree. Then the lowest average respondents answer is 4.21 included in the category of strongly agree.

In the purchase decision variable, the highest average answer of respondents is 4.48 included in the category of strongly agree with the high value of the purchase decision. Then the lowest average respondent's answer is 3.73 included in the agreed category, this means the decision to purchase a K-Pop cd album is very high.

\section{Multiple Linear Regression Analysis}

The results of multiple linear regression analysis can be seen in table 1.

Table 1. Result of Multiple Linier Regression Analysis

\begin{tabular}{cccc}
\hline Model & Unstandardized Coefficient & t. & Sig. \\
& B & & \\
\hline $\begin{array}{c}\text { A constant } \\
\text { Hedonic }\end{array}$ & 17.939 & 3.281 & .001 \\
$\begin{array}{c}\text { Motivation } \\
\text { Consumer } \\
\text { Attitude }\end{array}$ & 0.402 & 5.288 & 0.000 \\
\hline Source: SPSS Output 18 & 0.314 & 2.446 & 0.016 \\
\hline
\end{tabular}

Table 1 shows that the constant value $(\alpha)$ is 17.939 meaning, that if the hedonic motivation and consumer attitudes are absent or the value is 0 (zero), then the decision to purchase cd KPop album still occurs at 17.939. The decision to purchase a K-Pop cd album still occurs because there are other variables outside of this study that affect purchasing decisions.

The regression coefficient value of the consumptive behavior variable is positive (0.402). The positive coefficient indicates the relationship between hedonic motivation and purchasing decisions is a direct relationship. This means, if the hedonic motivation for the decision to purchase a K-Pop cd album has increased by one unit, then the decision to purchase a K-Pop cd album will increase too.

The regression coefficient value of the consumer attitude variable is positive (0.314). The positive coefficient shows that there is a relationship between consumer attitudes and purchasing decisions is a direct relationship. That is, if the positive attitude of consumers on the K-Pop cd album increasingly, then the decision to purchase the K-Pop album cd will increase.

\section{Determination Coefficient Test Results}

The results of the coefficient of determination test can be seen in table 2 . 
Table 2. Test Results Coefficient of determination $\left(R^{2}\right)$

\begin{tabular}{|c|c|c|c|}
\hline Model & $\mathbf{R}$ & $\begin{array}{c}\mathbf{R} \\
\text { Square }\end{array}$ & $\begin{array}{c}\text { Adjusted } \mathbf{R} \\
\text { Square }\end{array}$ \\
\hline 1 & $0.506^{\mathrm{a}}$ & 0.256 & 0246 \\
\hline
\end{tabular}

Source: SPSS Output v.18

It can be seen in table 2. that the Adjusted $\mathrm{R}$ Square value is 0.256 or $25.6 \%$. This value means that hedonic motivation and consumer attitudes influence the decision to purchase K-Pop cd albums by $25.6 \%$. And the rest $(100 \%-25.6 \%=74.4 \%)$ is influenced by other variables outside the variables used in this study.

\section{Hypothesis Testing with $t$ test}

Based on the test results in Table 1. that the use values of $t \mathrm{X} 1$ amounted to $5.288>\mathrm{t}$ table 1.97693 is supported with sig. in the amount of $0.000<0.05$. So, $\mathrm{H}_{0}$ is rejected so that it can be interpreted that the variable motivation hedonic (X1) a significant effect on purchasing decisions $(Y)$.

Based on the test results in Table 1. that the use values of $\mathrm{X} 2$ of $2.446>t$-table 1.97963 is supported with sig. of $0.016<0.05$. So, $\mathrm{H}_{0}$ in decline, so it can be interpreted that the variable consumer attitudes $(\mathrm{X} 2)$ significantly affects the purchase decision $(\mathrm{Y})$.

\section{Effect of Hedonist Motivation on Purchasing Decisions}

This study shows the results of a significant influence between hedonic motivation on purchasing decisions. There is a positive relationship between hedonic motivation and purchasing decisions that show a direct relationship. This explains that the K-Pop cd album can influence the purchasing decisions of KPOPSURABAYA community members. One of the influences that led to their buying decisions was their satisfaction because they had a collection of albums from their idol group and a sense of pride when possessing these items, and they had a high artistic spirit towards K-Pop music.

This means that this research is also in accordance with what was stated by Sumarwan (2011:25), motivation arises because of psychological needs such as satisfaction, pride, emotions and other subjective feelings. Thus, a match between hedonic motivation and the K-Pop cd album will greatly strengthen purchasing decisions.

This study is also in accordance with research conducted by Aldaning et I (2018) states that hedonic motivation influences purchasing decisions, and supports other studies by Kusuma et al (2013) emphasizing that emotional values such as pleasure to improve mood, get discounts, enjoy being with friends and or family, and following trends has a positive influence on purchasing decisions.

\section{Effect of Consumer Attitudes on Purchasing Decisions}

This study shows the results of a significant influence between consumer attitudes towards purchasing decisions. There is a positive relationship between consumer attitudes and 
purchasing decisions that show a direct relationship. This shows that positive attitudes given by consumers lead to positive actions in the form of purchasing decisions. Where the K-Pop idol has provided music that makes K-Pop fans happy with the provision of his CD album. That way fans will give a good rating in the form of a positive attitude which then fans will decide on the purchase of the K-Pop cd album, also these results indicate that the second hypothesis of "there is an influence of attitude towards the decision to purchase the K-Pop cd album" has been proven. This is consistent with what was stated by Mowen and Minor (2002) state that attitudes are the core of likes and dislikes for people, groups, situations, objects, and certain intangible ideas. Every element in this definition is very important to understand why and how attitudes are related in consumer behavior

The results of this study support the research conducted by Adilang et al (2014), Miauw (2016) and $\mathrm{Yi}$ et al (2013) states that consumer attitudes influence purchasing decisions. Consumer attitude is an important factor in making decisions when shopping.

\section{CONCLUSIONS}

The result in this research have significant influence of hedonic motivation to purchasing decision K-Pop CD album and also a significant difference between the attitudes of consumers towards the purchase decision of a CD album of K-Pop.

Acknowledgments: Further researchers are recommended to be able to examine other variables outside of this research variable by $74.4 \%$, such as the reference group, lifestyle, consumptive behavior, and so forth. Then there is the online research questionnaire data collection process, researchers can't find out if respondents who fill in more than once. It is hoped that for further research the researcher can include the identity column such as name and email address owned by the questionnaire filler. And if this happens you should do the recording manually so it is easy to identify anyone who has filled out the questionnaire.

\section{REFERENCES}

Adilang, A., Oroh, S. G. and Moniharapon, S. (2014) 'Persepsi, Sikap, Dan Motivasi Hedonis Terhadap Keputusan Pembelian Produk Fashion Secara Online', Jurnal Riset Ekonomi, Manajemen, Bisnis dan Akuntansi, 2(1), pp. 561-570.

Aldaning, A. P., Achmad, F. and Wilopo (2018) 'THE EFFECT OF EWOM AND HEDONIC MOTIVATION TOWARD BUYING INTEREST AND DECISION'. doi: 10.18551/econeurasia.2018-06.

Chart, G. (2019) Album Chart. Available at: http://gaonchart.co.kr/main/section/chart/album.gaon?nationGbn=T\&serviceGbn=\&targetTime=12\&hi tYear=2019\&termGbn=month (Accessed: 25 February 2019).

Dasuki, U. (2015) 'Pengaruh Sikap dan Motivasi Konsumen Terhadap Keputusan Pembelian T-Shirt Airplane Pada Distro Airplane System Bandung'.

Kapantouw, C. and Mandey, S. (2015) 'Pengaruh Sikap, Norma Subyektif, Dan Gaya Hidup Terhadap Keputusan Pembelian Handphone Asus Di Gamezone Computer Mega Mall Manado', Jurnal Riset Ekonomi, Manajemen, Bisnis dan Akuntansi, 3(2), pp. 706-718.

Kotler, P. (2003) Marketing Management. 11th edn. New Jersey: Prentice Hall Inc.

Kotler, P. and Armstrong, G. (2011) Marketing an Introduction. 10th edn. Indonesia: Perason.

Kusuma, G. W., Idrus, S. and Djazuli, A. (2013) 'The Influence of Hedonic Shopping Motivations on Buying Decision with Gender as Dummy Variable : ( A Study on Consumers at the Hardy 's Mall Singaraja , Buleleng Regency, Indonesia )', 5(31), pp. 241-247.

Miauw, K. Y. H. (2016) 'Motivasi Konsumen Dan Sikap Konsumen Terhadap Keputusan Pembelian Di Wild', Jurnal Manajemen dan Start-Up Bisnis, 1(5), pp. 567-575.

Mowen, J. C. and Minor, M. (2002) Perilaku Konsumen. Jakarta: Erlangga.

Schiffman and Kanuk (2008) Perilaku Konsumen. 7th edn. Jakarta: Indeks. 
Sumarwan, U. (2011) Perilaku Konsumen. 2nd edn. Bogor: Ghalia Indonesia.

Utami, C. W. (2010) Manajemen Ritel: Strategi dan Implementasi Ritel Modern. 3rd edn. Jakarta: Salemba Empat.

Wattimena, Y. O., Lestari, R. B. and Widagdo, H. (2012) 'Analisis Pengaruh Sikap Konsumen Terhadap Keputusan Pembelian Jasa Asuransi Kesehatan XYZ Di Palembang', Asian Journal of Business Management, 4(2), pp. 105-110.

Yi, J., Yuan, M. F. and Kumah, S. (2013) 'The Attitude, motivation influence people's buying Luxury goods: A survey of Chinese in China', IOSR Journal of Business and Management, 15(3), pp. 15-24. doi: 10.9790/487x-1531524.

Yuldinawati, L. and Ayuningsari, A. (2016) 'Hedonic Shopping Motive As A Routinization Habit On The Consumer Purchase Decisions At Starbucks Coffee', (Isclo), pp. 1-5. doi: 10.2991/isclo-15.2016.1.

Zaini (2017) DINAMIKA PERKEMBANGAN MUSIK K-POP DALAM PERSPEKTIF INDUSTRI BUDAYA.

(C) 2020 by the authors. Submitted for possible open access publication under the terms and conditions of the Creative Commons Attribution (CC BY SA) license (https://creativecommons.org/licenses/by-sa/3.0/). 